\title{
The right to life of a fetus: Abortion is a serious moral and social problem of the young people in Vietnam
}

Lan, Nguyen Thi $\measuredangle$

De La Salle University, Manila, Philippines (maryxinvang@gmail.com)

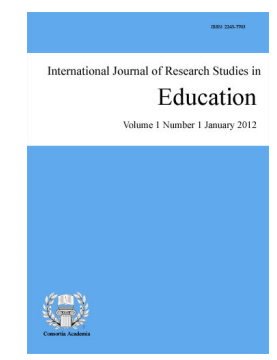

Accepted: 18 October 2021 Online ISSN: 2243-7711

OPEN ACCESS

\section{Abstract}

In recent years, the constant changes in the economy, science, and especially the outstanding development of information technology, which have made people's lives improving. Nevertheless, unfortunately, moral values are eroding by pragmatism materialism, and hedonism. These make people increasingly lose their conscience. They can do anything for their own interests, even daring to give up a life that has not yet been born by aborting. Actually, abortion among young people is now a serious and controversial problem in many countries around the world, Vietnam is a typical country on this. Some support the rights and life of the embryo/fetus, while others support abortion for various personal and social reasons. Perhaps we will be shocked and heartbroken when we know the terrible numbers that have been reported about abortion in the world in general and Vietnam, my country in particular. In this article, the researcher does not have the ambition to give a clear and coherent point of view, also do not intend to state what is allowed and what is prohibited unequivocally, and much more do not open a new independent solution or a right view or an outlet for the debate around abortion. The researcher tries to approach and analyze the problem based on the notions, theories, the moral laws of some religions, the legal laws on protecting a fetus' life. So that, those who were, are, and shall intend to have an abortion can make the right decisions and appropriate conscience, dignity, and morality.

Keywords: abortion, young Vietnamese people, morality, right, right to life, laws, conscience 


\section{The right to life of a fetus: Abortion is a serious moral and social problem of the young people in Vietnam}

\section{Introduction}

\subsection{Current state of abortion}

Today, along with economic and scientific development, abortion is also increasing among young people. In recent years, those who are concerned about this issue surely were startled by the statistics and reports on the current state of abortion in the world. According to WHO statistics, the number of abortions in the world has increased over time. In 2017, WHO reported, the global number of abortions was 55.7 million cases; of which the number of "unsafe" abortions was 25.5 million. This means that almost half of all abortions were unsafe (Ganatra et al., 2017). Then between 2015 to 2019, there were 73.3 million abortions each year on average, which corresponded to a global annual rate of 39 abortions per 1000 women aged 15-49 years. These estimates reflect that $61 \%$ of unintended pregnancies ended in abortion. It has been estimated that $45.1 \%$ of abortions are unsafe (Bearak et al., 2020), it is causing 70,000 maternal deaths each year or one in eight pregnancy-related deaths among women. That translates to seven women died per hour because of this reason (Cohen, 2009).

Let's look at the number of abortions in Vietnam, the country that I want to aim in this issue. Also, according to the World Health Organization (WHO), Vietnam is one of the five countries with the highest abortion rate in the world and the country with the highest abortion rate in Asia. The official annual number of abortions is 300,000 . Surprisingly, among them, about 180,000-200,000 (60\%-70\%) cases are young people, mainly students aged 15-19 years old, 20-30\% are unmarried women, and Two out of five women of reproductive age have had at least one abortion (Ngọc Vy, 2021). These are very alarming numbers. That's not to mention abortions in private institutions, underground abortions, and unreported disguised abortions. Abortion is not only not banned by the government but also encouraged and promoted in many different forms and even considered as the right of each person. In addition, modern and increasingly sophisticated medical facilities make it easier to execute abortion. Just type the word 'abortion' on Google, we will get hundreds of pages advertising abortion services. Not only on websites but also in the ways of cities, we still see billboards advertising this service.

The above situation is an alarm bell about the trend of deviant living and moral decline in a part of young people. So, the cause from? Like many other Asian countries, in Vietnam gender issues, sex is still considered a sensitive topic, almost a taboo topic in social life. Many parents still have the mentality of avoiding when talking to their children about gender and sexual issues. Meanwhile, books on this topic, especially documents and movies online are quite popular. Children's nature is curious, so they often quietly learn on their own, without being guided by the right perception and conception from people with life experience, leading to negative and out-of-control behavior (Linh Trang, 2020).

There are many reasons leading to abortion, which first of all comes from young people. They lack knowledge, do not control themselves, or prefer a life of enjoyment, indulgence, and do not respect the moral standards of the community or the laws of religion. And there are countless reasons given by young people to justify their actions. On the family side, with the development of the economy, parents are so absorbed in their work that they have little time to take care of children. Many families leave their children to school and society, and by the time they find out their child is pregnant, it's too late (Ngoc Ha, 2014). Besides, the fact shows that private medical centers, even at public hospitals consider abortion as a very normal thing. They even "promote" abortion instead of counsel, and dissuade people to stop abortion. They believe that the fetus is not yet human, so it has no human rights. In addition, the policies of family planning of the government have been also drastically imposing on the people for the sake of regulation of population. That ways of thinking have caused millions of 
The right to life of a fetus: Abortion is a serious moral and social problem of the young people in Vietnam

little beings to be deprived of the right to live before they have seen the sun (Quang Huyen, 2010). This issue not only brings pain and anxiety to parents but also has an urgent impact on the social situation and those who have a conscience responsible for this issue. Abortion has consequences not only for health, physiology, and psychology, but also for the future, quality of race, and social and religious life. It not only hurts women after getting married but also makes them feel guilty because of the wounds they have caused. Abortion has not only failed to solve the problems of women and families but also opened another wound in their hearts, churches, and also society.

According to the study by Khanh Trang (2004), in Vietnam, menstrual disorders make up 10-14\%; placental retention accounting for $2.5-3.7 \%$ or uterine trauma as uterine perforation, cervical injury, endometrial damage-causing uterine bleeding after an abortion. Furthermore, Abortion causes the psychological trauma after abortion of young people often manifests as mental depression, accounting for $27.5 \%$ of abortion cases. Of which, the mild level accounts for $63.64 \%$, the average level is $27.27 \%$ and the severe degree is $9.09 \%$ (. Severe cases are often related to complications and do not receive emotional support from the family

According to Tsevat et al. (2017) estimating $18.5 \%$ were infected after abortion, it is most often pelvic inflammatory disease (PID). Pelvic inflammatory disease is difficult to diagnose and manage and this is the cause leading to infertility in women. A US study reported that, after 1 time of Pelvic inflammatory disease PID, the rate of infertility is $10 \%$, if there are two times of PID, the rate of infertility is $30 \%$, and after 3 times of PID, the infertility rate increases to $60 \%$. Miscarriage: due to the high rate of cervical trauma in abortion, especially in adolescents (incomplete genitalia) is the cause of increased miscarriage rate in the next pregnancy, a report Reports in the US suggest this rate may be 30-40\%. (Burkman et al., 1984). Some studies have shown an association between a history of abortion and pre-eclampsia as well as an increased risk of breast cancer (Xu Xiong, 2002)

This article aims to young Vietnamese people, where mainly atheists and Buddhists, Catholics make up a minority (7\%). They have different views on life and abortion. Therefore, this research paper is not intended to prove the right or wrong on abortion of an individual, country, or religion. Instead, the article will provide horrible numbers about abortion in the world and typically in Vietnam to see this scary "murder" situation. Then, this article is also to provide an overview of the right to life of the fetus and world views when answering the question: Is the fetus considered a human being? From there, to learn about international, national, and religious regulations on fetal rights and abortion. At the same time, we point out the morality of abortion from the perspective of some scholars, society, and religions, especially Catholicism. Finally, it is the researcher's criticism, comments, thoughts, and suggestions. Hopefully, by evaluating and analyzing based on the arguments, theories, laws, and morals about the protection of the right to life of the fetus and the issue of abortion of some countries, organizations, and religions in the world will reach anyone who has and is contemplating abortion. So that they can consider and make the right and ethical decisions of human conscience. So that, those who have had an abortion know how to regret it and do many good deeds to contribute to protecting life and fighting against abortion.

\subsection{The Significance of the Study}

There have been many studies talking about fetal rights and abortion. But most of those studies only show a certain field that people have the right to have an abortion or not to have an abortion by basing on a national law or moral regulation of a certain religion. That is very limited. In this study, first of all, the researcher will provide to synthesize materials, laws, and rules of morality related to fetus's right and moral abortion from different countries, and religions. Then, analyzing them to help young Vietnamese in general, and those who are intending to abort to know and understand more about fetus' rights and moral abortion. So that, they can stop abortion. Moreover, the researcher would like to study more about perspectives of nations, religions, and the world on right to life of a fetus and moral abortion. As a Catholic religious sister, this is very significant for the researcher-self as well as our congregation and those who care about the right to life of a fetus and abortion. Since, our first and foremost mission is selflessly to serve women and youth in the area of education, social work, 
health care, morality, and faith (Lovers of Holy Cross [HLC]). We especially concern about the right to life of the unborn, educate the role of women in the family and in society, and restore the dignity of women who have gone astray (Those who are pregnant without marrying) (HLC). This research paper will provide more accurate, opening views of a fetal right and moral abortion when we give ourselves to serve atheists or other people of religions in this field.

\section{Methodology}

In carrying out and developing the research topic: The See, Judge, and Act method is used. In fact, "in terms of research methods, 'See-Judge-Act' could be described as a type of action research... [This method] can be described as a holistic approach geared toward the grasp of truth about reality from a most comprehensive perspective" (Fernando, 2010, p. 5). In the SEE aspect, the horrible abortion numbers are raised to see the state of abortion in Vietnam. And its causes and consequences for individuals and society are also given briefly in this section. This is already done in the introduction. In the JUDGE aspect, the researcher will give the analysis or critique of the fetus' right and abortion issue in the light of world and national laws, related theories, scholars, theologians, and ethic religions. By this part we will see different perspectives on fetus' right and abortion issue. This part is the foundation for the Act part, which is suggestions to reduce status of abortion and build the better Vietnamese society.

\section{Discussion}

\subsection{The conceptions of Fetus's Right to life and Moral Abortion}

There are different conceptions about the right of the fetus, and ethic/moral abortion. It is depending on who they are, what the nationalities that they belong to, and what religions that they are believing in. Some suppose that the fetus's right is the right of human being because fetus is a human, while some said, fetus is not human yet, so they do not have completed right as a human. In this study the researcher just mentions some conceptions on the fetus' right. However, before talking about the fetus' right, we find out the basic concepts of human right to life first.

The concept of the human right to life - The right to life is a basic and especially important human right, which is recognized in many international legal documents, specifically: Article 3 of the 1948 Universal Declaration of Human Rights for the first time mentioned the right to live with content: " Everyone has the right to life, liberty, and security of person (Kessler, 2003). Thus, in this article, the Universal Declaration of Human Rights has indicated three different groups of rights; rights and viability, or understand the right to life in biological terms and dream more broadly as the right to comfortable living conditions, individual liberties, and the right to personal security. Furthermore, the above content is further concretized in Article 6 in International Covenant on Civil and Political Rights (ICCPR) Clause 1: "Everyone has the inherent right to life. This right must be protected by law. No one may be arbitrarily deprived of his life" (World Association for Medical Law, 1994).

Besides, a number of other treaties such as the Convention on the Rights of the Child (CRC), Convention on the Prevention and Punishment of the Crime of Genocide (CPPCG), International Convention on the Suppression and Punishment of the Crime of Apartheid (ICSPCA), General Comment No. 6 of UN Human Rights of Council (UNHRC) adopted at the 16th session in 1982, General Comment No. 14 (23rd session in 1984) .... also emphasized the content of the human right to life. First, the right to life is a basic human right that in any circumstances, even in a state of national emergency cannot be violated... (Inazumi, 2005). Second, the right to life should not be understood in the narrow sense of just the integrity of life. Furthermore, this right includes aspects that ensure human existence (Kuźniar \& Odrowąż-Sypniewska, 2016). Thus, ensuring the right to life requires states to take measures to reduce child mortality and increase life expectancy, in particular measures to eliminate malnutrition and epidemics. Meaning includes both passive and active measures. because

50 Consortia Academia Publishing (A partner of Network of Professional Researchers and Educators) 
The right to life of a fetus: Abortion is a serious moral and social problem of the young people in Vietnam

the rights to life, bodily integrity, basic nutrition and health, and so forth are the basic rights of humans (Miller 2007 , p. 3). Third, preventing criminal acts that endanger or deprive people of life is also a very important measure to ensure the right to life. The States should take measures to prevent and punish arbitrary deprivation of life by any actor, including by state security forces (Bychawska-Siniarska, 2017). In this regard, abduction and disappearance are also considered as forms of deprivation of the right to life. Therefore, the States are obliged to put in place effective measures and plans to prevent and investigate such cases.

Thus, the right to life is not given by the state or anyone, but by oneself as a human being (Lysaught et al., 2012). The question here is whether the embryo (fetus) is considered human and enjoys special protection? When is the origin of a human being, at birth or while still a dependent fetus?

National perspectives and laws on Fetus' Right - The right to life is a fundamental and central human right. Although the right to life of the unborn child is a matter of contention because acknowledging it in many cases goes against a woman's right to freedom and privacy. Consequently, with regard to the life of a fetus, the majority of international law, international and regional human rights agencies, as well as courts around the world, have so far clearly established that any Prenatal protection measures must be consistent with women's human rights. An increasing number of Supreme Court and government decisions around the world are recognizing the right to abortion, or in some cases, the right to privacy leading to the right to abortion. However, there are still many organizations, religions, and countries that still condemn and strongly oppose abortion. Because the embryo or fetus is also a human being, one's life (George \& Lee, 2009). To be more precise, the embryo and fetus have human potential, which means that if the fetus is carried to full term, the fetus will develop into an adult with full social and political rights (Miklavcic, \& Flaman, 2017). So, abortion is equivalent to murder (Brown, 2000).

When talking about the rights of the fetus, Cao et al. (2018) definite that fetal rights are the moral rights or legal rights of the human fetus under natural and civil law. Regarding the right to life of the fetus, although there are currently conflicting views. However, many organizations, religions, and countries still strive to protect the right to life of the unborn child. For example, some international legal documents also provide for the protection of the rights of the fetus. Specifically, the first part of the United Nations International Convention on the Rights of the Child (CRC) noted: Bearing in mind that "because of their physical and mental immaturity, children need special protection and care, including appropriate legal protection before and after birth" as set forth in the Declaration of the Rights of the Child. According to this provision, the fetus also has the right to be protected and cared for in order to maintain the health and condition of the life. Or as the 1969 American Convention on Human Rights (ACHR) in Article 4 stipulates: "Everyone has the right to respect for life, this right is protected by law and in general, from the moment of conception, no one is subject to arbitrary depriving us of the right to life".

Some countries have adopted different legal frameworks to protect prenatal life such as Some countries recognize prenatal life as a recognized right in national constitutions such as Guamethala and Chile; Some countries aim to ensure equality of life for both pregnant women and unborn children as in the national constitutions of Ireland and the Philippines, and Some countries assert the dependence of the fetus on the mother's body and place the mother's rights above such as Poland. (Turner, 2010). Several groups whose strategies have promoted the recognition of the right to prenatal life have relied on the context of the reform legislative process, legislative initiatives, the courts, and the challenges that seek to extend the legal protections. protection of the right to prenatal life in many countries (WHO, 2017). For example, in 2010 the Dominican Republic adopted a new constitution, which recognizes the right to life from the moment of conception (Larios, 2015). In 2008 and 2010, the state of Colorado - USA, and in 2011, the state of Mississippi took the initiative to amend the constitution by stating that the concept of the beginning of life is from the moment of fertilization. According to which zygote, embryo and fetus are human beings with all rights guaranteed to persons under their state constitutions (Miklavcic \& Flaman, 2017). Since 2008, at least 16 Mexican states have amended their constitutions to protect the right to life from conception or conception (Paine et al., 2014). 
Religious Perspectives on Fetus' Right and Moral abortion - There is an opinion that: "It is impossible to be certain when human life begins; because it is a religious question that cannot be proved by science" (Keown, 1995). So, when we delve into the debate about the right to life of the unborn baby, we will need to keep in mind religious views. In general, the issue of the right to life of the fetus is a matter of concern to many religions, the teachings often advise people towards the good, most religions emphasize the issue of procreation. Therefore, most religions tend to advise against, even banning abortion, along with that is the recognition of the right to life of the fetus.

Buddhism's Perspective - According to Buddhism, Damien Keown (1995) in "Buddhism and Bioethics" says that a person's life begins at conception, the point at which, according to him, consciousness (viānāna) comes into being. Keown considers consciousness to be the most essential of the five aggregates that make up a person and concludes that abortion is against Buddhist ethics, breaking the first precept is not to take life. Keown argues that the preponderance of the Buddhist tradition is its staunch anti-abortion.

The point of view of Buddhism on the issue of abortion, first of all, Buddhism is a compassionate religion, always respecting life and protecting the lives of all species. Buddhism does not oppose birth control methods but does not support abortion. Because the fetus is a germ, a life, so it needs to be protected. Buddhism considers life or life to be present at the beginning of conception. Conception is considered the natural process that takes place when three conditions are fulfilled: there is intercourse, the woman is in the fertile period, and a "spirit" or deity is present.

The Dalai Lama, in answering this question to Western scientists, affirmed: "Buddhism holds that consciousness enters the living being from the very first moment of conception, because where the blastocyst is still considered an organism. So, they view abortion as taking a person's life" (His Holiness the Dalai Lama, 1996, p. 11). According to the doctrine of reincarnation, the person at the moment of conception is the same as the born one, (Tsomo, 2012, p. 120). There is no qualitative difference between an unborn fetus and a born individual. If a mother aborted, that mother not only killed a human being but also implies some other grievous sins for the mother, like greed, hatred, and delusion. Greed represents a passionate attachment and determines the persons who decide to abort to consider only their own interests and comfort (Florida,1991). The Buddhist viewpoint is clear: the mother is not the owner of the being she wears in her womb. This being is a different person since the very moment of conception, having his own identity and being distinct from the mother's body (Damian, 2010, p. 318).

According to Buddhist teachings, the act of violating the precept to kill must meet five conditions, which are: A living being / Consciousness knowing that it is a being / Intent to kill / Find a way to kill / Result that sentient being died. According to the above conditions, a mother (Buddhist) having an abortion is a violation of precepts, committing a great sin Mckerlie, (2005). However, Buddhism allows abortion in some cases. For example, when abortion is induced for saving the mother's life (Florida, 1991).

Hinduism's Perspective - Like many religions of the world, in Hinduism too, abortion is morally and ethically a wrong act (Yadav, 2018). Many Hindus believe that the soul and matter that form the fetus are united from the moment of conception. Hinduism is generally opposed to abortion except where it is necessary to save the mother's life.

According to the doctrine of reincarnation, which sees life as a repeating cycle of birth, death, and rebirth, is basic to Hindu thinking. It is strongly against abortion when it declared that a fetus is not developing into a person but is a person from a very early stage. "The fetus is not developing into a person but, rather, is already a person at the moment of conception". It contains a reborn soul and should be treated appropriately (Goold et al., 2009). Ahimsa (non-violence) teaches that it is wrong not only to kill living beings but also to kill embryos. Although the śruti texts (the central canon of Hinduism) do not explicitly forbid abortion, they clearly postulate protection for the embryo and assert that abortion is a morally intolerable act (Damian, 2010). Moreover, Hindus think that if a fetus is aborted, the soul in it will suffer a great deal of karma. It is deprived of the opportunities 
The right to life of a fetus: Abortion is a serious moral and social problem of the young people in Vietnam

one might give it to create good karma and is immediately sent back to the cycle of birth, death, and rebirth. Hence abortion hinders the spiritual progress of a soul. Hindus believe that all life is sacred, to be loved and revered, all life is sacred because all creatures are manifestations of the Supreme Being.

Ahimsa (non-violence) teaches that it is wrong not only to kill living beings but also to kill embryos. Although the śruti texts (the central canon of Hinduism) do not explicitly forbid abortion, they clearly postulate protection for the embryo and assert that abortion is a morally intolerable act (Damian, 2010). Ahimsa (non-violence) teaches that it is wrong not only to kill living beings but also to kill embryos. Although the śruti texts (the central canon of Hinduism) do not explicitly forbid abortion, they clearly postulate protection for the embryo and assert that abortion is a morally intolerable act. (Damian, 2010). Nevertheless, in contemporary India, confronted with serious public health problems, uncontrollable population growth rate, and large-scale illegal abortions, abortion has been legal since 1971. Medical Termination of Pregnancy Act allows abortion if the continuance of the pregnancy involves a risk to the life of the pregnant woman or will injury her physical or mental health if the child will suffer physical or mental abnormalities or the pregnancy is caused by rape or the failure of a birth control device. (Damian, 2010). We can conclude that from the Hindu point of view, abortion is both a moral and social transgression.

Catholic's Perspective - In Catholicism's view, human life is a precious gift from God because man is created in the image of God, is something sacred that comes from God and belongs to God. Human life is the foundation of all welfare, the source and the indispensable condition for all human activities and all sympathy in society. Respect for life is the source of all respect for fundamental human rights. Therefore, murder is a very serious sin, because it is a crime against God, who alone has the right to life and death, and a crime against others because we have deprived them of a very precious value. God commanded: "You shall not murder" (Exodus 20:13; Deut. 5:17). For, Man is created by God; He has seen the person that He created in the womb. People see it when it is just a small embryo with no definite shape and foresee what it will be like tomorrow. For, from the very beginning of his infancy, man has been written by God in the "book of life" and his days are counted: "Your eyes beheld my unformed substance. In your book were written all the days that were formed for me, when none of them as yet existed. "I am a fetus; your eyes have seen it; All the days of my life that are set aside for me are recorded in Your book before the first day of my life begins" (See Psalm 139). According to the Bible, man is already the object of God's providential love even in the womb. In the Gospel account of the encounter between Mary and Elisabeth, the author Luke shows that the two fetuses in the womb of two mothers were real people with their own personalities. The presence of the Incarnation Jesus fetus in the womb of Mary brought joy and salvation to the fetus of John the Baptist, who was conceived for six months in Elizabeth's bosom, and it made John the Baptist jump for joy, even though he was still in his mother's womb. (See Luke $1: 39-45)$.

The Catholic Church has always maintained that human life exists from the moment of fertilization, that is when the sperm fuses with the egg. Many Church documents show us the position of the Church in this matter. According to the position of Pope Pius XII in his Address to the Biological Union of Saint Luke on November 22, 1956: " All activities that directly lead to the destruction of unborn human life must be excluded, whether such destruction is determined as an end or solely as a means to an end " (Pope Pius XII, 1956).

Pope John XXIII also reaffirmed that Human life is sacred because from its very origin it requires the creative action of God. Then, at the Second Vatican Council, the Church restated her constant and unwavering teaching: Life from the moment of conception must be guarded with great care; Abortion and murder are heinous crimes disgusting (Gaudium et Spes, no. 51). The Holy See reaffirmed it in the " Charter of the Rights of the Family ", No. 4, that: " Human life must be absolutely respected and protected, from the moment of conception. This means that Abortion is a direct violation of the fundamental right to life of the human being; respect for the dignity of the human being excludes all experimental manipulation or exploitation of the human embryo; children, both before and after birth, have the right to special protection and assistance, as do their mothers during pregnancy and for a reasonable period of time after childbirth (The Holy See, 1983). 
The Congregation for the Doctrine of the Faith, in its Declaration on Procured Abortion (Paul VI, November 8, 1974), no. 12-13, affirms, "from the moment the fertilized egg begins a new life which is neither the father's life nor the mother's life, but that of a new human being, which can develop on its own. It would never have become human if it had not been human at that time (...)". And that eternal certainty has been confirmed by modern genetics and shows that, from the first moment, the future development program of that organism is determined a human being, a human being particularly with well-defined characteristics. The adventure of life in a human begins at the moment of fertilization. Even if the presence of a spiritual soul cannot be ascertained by empirical data, the results themselves of scientific research on the human embryo provide "a valuable indication for discerning by the use of reason a personal presence at the moment of the first appearance of human life: how could a human individual not be a human person? (John Paul II, Evangelium Vitae, no. 60). Thus, "the deliberate decision to deprive an innocent human being of his life is always morally evil and can never be licit either as an end in itself or as a means to a good end. Nothing and no one can in any way permit the killing of an innocent human being, whether a fetus or an embryo, an infant or an adult, an old person, or one suffering from an incurable disease, or a person who is dying." (Evangelium Vitae, no. 57). Catholic's moral teaching has always regarded abortion as a grave sin: "...Direct abortion, that is to say, abortion willed either as an end or a means, is gravely contrary to the moral law" (CCC. 2271), even the persons who involve directly in abortion also have to take great responsibility for that act of collaboration, "Formal cooperation in an abortion constitutes a grave offense" (CCC 2272).

In all the crimes that man can commit against life, intentional abortion is a particularly serious one. This is a very disgusting type of murder because the victim in this case is an innocent person who has not been able to defend himself/herself. Because Abortion is the removal from the womb of an unviable human by some human method, either by killing it before removing it from the womb or by making it risk its own life outside the womb (Peschke, 2012).

Catholic morality categorically rejects/bans all forms of abortion for personal, eugenic, and social reasons. That consider merely a form of killing innocent children. The Catholic Church's position on abortion has to be summed up in its argument with four propositions as follows: "(a) God alone is the master of life, (b) thus no human being has right to take the life of the innocent; (c) and therefore once human life begins from the moment of conception, (d) abortion, whether carried out at any point in the development of the fetus, carries the meaning of the act of eliminating the life of an innocent human being" (Evangelium Vitae, no. 53). Directly destroying an innocent person's life is always inherently evil. Abortion, its nature is bad, it is not bad because the Church bans it. The Church only bans abortion for abortion is inherently bad.

According to the current Canon Law, Code of Canon Law (1983), can. 1398 prescribes discipline for the destruction of fetal life: "A person who procures a completed abortion incurs a latae sententiae (automatic) ex-communication." Thus, when abortion is effective, not only the woman who has an abortion but also the person who executes or helps to accomplish it will also be excommunicated. The excommunicated person, if he is a minister of the Church, in addition to losing their spiritual communion, they are also restricted from carrying out the ministries according to their function.

The perspective of theologians and scholars - There are many theologians and philosophers around the world who have also expressed their views on the issue of the right to life of the fetus. For instances:

Theologian Bernard Haring stated that there is no visible sign of God's creative presence in this world more pronounced than the beginning and development of man. Eggs ripen at once a month inside a woman's ovaries, the hundreds of millions of sperm produced each month are not yet human. However, they carry a wealth of information within them. The combination of these two elements creates a new one and marks the beginning of a new human life (Bernard Haring, 1981, P.6).

The theologian Théodule Rey-Mermet also asserted that: "Just read Claude Edelmann and JM Baufle's admirable work on the "Early Days of Life" to know that between conception and birth, there is a complete 
The right to life of a fetus: Abortion is a serious moral and social problem of the young people in Vietnam

continuum. The exact moment when the newly fertilized egg that splits in half is the beginning of a new person's existence. For that person, this time is the zero hour of his/her first day. That is the general opinion of biologists. All the rest of the discussion is only literature or philosophical treatises (Van Tam, 2004).

Doctor A. A. Tomatis also asserts: The true beginning of the human adventure in which the fetus embarks is decided the moment conception is made in the fertilized egg... That moment is the moment of the real beginning of every human being. It is a true starting point for our commitments. Subsequent actions that are nominally forward will be only vague simulations. That is why birth is born. Conception marks the beginning of the journey, rather than birth, which people are accustomed to referring to indicate this emergence. There was life at that time, at the beginning (Tomatis, 1981, pp. 233-234).

Until now, however, the question: When is the fetus considered a being with full humanity? It is still a matter of debate and there is no definitive answer. But the general view of theologians as well as scholars in general and biomedicalists in particular, all accept that after the egg is fertilized, the genetic pattern has been determined. There is a human life separate from that of the father and mother, with a unique set of genetic codes (DNA) that never repeats, although its DNA system is not yet functioning (Haring, 1998, p. 7). The very moment when the newly fertilized egg splits in half is the beginning of the existence of a new human being. And from that moment a human being begins a life of its own. A human being fully outlined, covered with a full gene, not only of what is needed to make a person but also of the other secondary characteristics to form a certain person, such as black hair or blue eyes... Although the newly fertilized egg is still dependent on the mother's life, it nonetheless has such independence that it can be transplanted into a uterus other than the human uterus. His/her mother and he/she could grow up where the genetics he received from the first moment remained unchanged. From that moment on there was a small one separately, individual person (Nguyen Van Tam, 2004, p. 97).

Therefore, destroy a human embryo or fetus is precisely to destroy a new, distinct and complete human organism, an embryonic human being. Of course, people with inside the embryonic, fetal and early little one levels can't but exercising intellectual features ordinarily done through maximum people at later levels of maturity. Still, they've in radical, which means they are the root form those very capacities. As human beings are intrinsically valuable and deserve full moral respect in virtue of what they are, it follows that they are intrinsically and equally valuable from the point at which they come into being. Even in the embryonic stage of our lives, each of us was a human being and, so such, worthy of concern and protection. Embryonic human beings, whether brought into existence by the union of gametes, somatic-cell nuclear transfer or other cloning technologies, should be accorded the respect given to human beings in other developmental stages. Their right to life should be acknowledged and respected (George \& Lee, 2009)

\subsection{Ethic Perspectives in the eyes of advocated abortion}

Most advocates of abortion are people who follow the Ethics of feminisms, Ethics of Egoism, and Ethics of Utilitarianism. However, these theories are flawed and morally absurd.

According to Ethics of Feminism - women's rights include issues related to freedom of marriage, equality in the family, promotion of physical integrity, autonomy, and reproductive rights for women (Narayan, 2018). Feminists have a simple slogan: "My body is my own" to assert their right to self-determination (UNFPA, 2021). In other words, women have the right to have an abortion because the fetus is in their womb and the right to have an abortion is fundamental to a woman's progress. They believe that any pregnant woman has the freedom to choose. They also argue that it would be unfair to limit a woman's freedom of choice by forbidding them to have an abortion. Furthermore, feminists know that human life begins before birth, but even if unborn children are considered human, they have fewer rights than women. Therefore, a woman still has the right to have an abortion. Moreover, they assert that having more unwanted children born into the world is to results in mistreatment and abuse of them only. Therefore, abortion is accepted. (Thuy Duong. 2005).

However, feminism exposes many flaws when applying to the abortion issue. Because, in reality, most 
children who are abused have had their parents' wishes for them to be born. The abuse and maltreatment of children in society have not decreased since abortion was legalized, on the contrary, it has increased appallingly (Bitler \& Zavodny, 2002). So, is feminism right when it overemphasizes women's right to self-determination and imposes the position and value of the child in a society that must be recognized as an excuse to defend abortion?

The argument that abortion reduces women's suffering and increases their family's happiness is also conjecture. No one knows for sure that after an abortion a woman is not haunted because she has just abandoned their "potential child". No one is sure that this event does not affect marital relations and other relationships in the family. More importantly, abortion can harm a woman's health, if severe, lead to infertility in the future. Therefore, no one knows for sure that abortion can bring more happiness than keeping the pregnancy or not?

Besides, the excuse of "my body is mine" to let the woman be free to have an abortion is also challenged. In terms of power relations between the woman and the embryo, it is not fair. The fact that an adult with full will and choice decides to abort the life of an embryo/fetus that may have a desire to live, is provoking a mixed reaction. In terms of the substance of the act, abortion certainly has enough elements to constitute an actual act of murder. Furthermore, abortion is never a personal choice, it is social because there are always at least two people involved with the embryo. If we assert that the fetus is small, so there is no social dimension, it is tantamount to denying that humans are not social at all. Those who are willing to discard human life as a commodity; also consider all human life to be nothing more than a commodity. The pro-abortion movement seems to be undermining the dignity of women. Women's rights are never linked with abortion rights (Rickie Solinger, 2019).

According to the Ethics of Egoism - Each person has the right to take action to achieve his or her own happiness. Egoists say that moral agents must do what is in their own interest. Basically, it is a necessary and sufficient condition for morally correct action, which is right that can maximize someone's own self-interest. This means that they only follow morality and do certain actions for their own benefits, then those actions are right (Kao, 2019, p. 37). This theory basically supports abortion, because it brings benefits exclusively to the pregnant woman. At the same time, doctors - who conduct abortions will have a certain amount of revenue, after successfully removing the fetus from the woman's uterus. They argue that an unborn baby cannot be considered a real person and that whoever's body has complete authority. They have the right to keep or abort a pregnancy, especially those who have unwanted pregnancies because of rape, broken plans, or poor economic conditions. Under the lens of Egoism, abortion is reasonable because it will lead to individual happiness and will not affect the collective good. Therefore, if anyone prevents abortion, it is a serious violation of individual rights. Abortion is thus a form of long-term personal gain for women.

However, the question here is whether a person only pays attention to his own interests and deprives others of life, while that person (the fetus) is unable to protect himself/herself, is it an action worth supporting? The selfish theory is wrong and creates many inadequacies in how to deal with this problem. It is a selfish, insensitive, and inhuman way of life. What will this society be like when people live this way of life? The right to life does not depend on the age, weight, or size of the child. The fetus has no less right to life than any older person, even in the case of its mother. The comparison between the interests of the child and the interests of the mother is a lame, unbalanced comparison. The nature of abortion shows that it is the mother who has tried every way to fight the life of her own child.

According to the Ethics of Utilitarianism - Utilitarianism's essence is to increase pleasure and reduce suffering; each person must have the duty and responsibility to take care of themselves in terms of material and spiritual life, then take care of others depending on the situation (Fieser, 2017).

Answering the question of whether abortion is allowed, the utilitarian theory argues: Abortion does no harm to anyone, can bring more happiness than unhappiness to pregnant women, as well as reduce the burden on women and society. Because to control population growth in some countries, the authorities introduced legislation and allowed abortion. They argue that abortion will bring benefits to the whole society. If there is no husband, a woman giving birth not only suffers from material hardship but also suffers from family and society,

56 Consortia Academia Publishing (A partner of Network of Professional Researchers and Educators) 
The right to life of a fetus: Abortion is a serious moral and social problem of the young people in Vietnam

especially that pregnant woman lives in conservative families and communities. They can fall into a dead end because of the prejudices of those around them. If they keep the fetus, they may face economic difficulties, and may even be deprived of opportunities for advancement in life. Obviously, the woman's suffering is real, while the fetus's suffering is only in potential form. If it is weighed and measured, the Favoritism recognizes abortion as a legitimate thing and should be done.

However, Utilitarianism was quickly disproved on several points; they do not fully understand the harmful consequences it brings to society when its pure ideas are implemented thoroughly. For example, if you are a believer in the basic idea of Utilitarianism, then you will have to play the murderer many times in your life to satisfy your beliefs. Likewise, a pregnant woman is given one more chance to have fun, while the fetus is brutally deprived of the chance to live.

The claim that abortion is for controlling population growth and improving quality of life is not at all convincing. It is a fact, as a result of the family planning program, many countries around the world are experiencing a shortage of workers, affecting the economy. Furthermore, overpopulation in a country is caused by other problems, not because of forbidding abortion. And if there is a population-related problem that has a disastrous effect on our quality of life, the right solution is not to kill off a portion of the population of that country. As a result of abortion, the family is harmed and society is threatened. Everyone knows that the population of European countries is decreasing, with medical advances, people live longer, so there are more and more old people but fewer young people, in order to have workers, they have to hire foreigners.

The justification that abortion saves the baby from suffering in the future is also uncertain. This is just an excuse for abortion because we are uncertain about the state of the future. Those who think that an embryo is just "a potential human" so they have the right to have an abortion are wrong and baseless. For if it is born, embryos can develop into normal people full of will, can be talented. Moreover, if using the excuse that the embryo does not have a sense of self to remove it, it is also the same as killing the infant. For, according to scholars, children only have a sense of self and knowing who they are when they are about two or three years old (Beran et al., 2012, p. 12). So, if this reason is used to justify abortion, is it also used to justify killing infants under the age of three? the answer is no, committing murder under the age of three is the same as murdering an adult.

\subsection{Personal criticisms and suggestions on the fetal right to life and abortion}

Criticisms - Although abortion advocates vehemently claim that abortion is a personal choice, more than ever, it is clear that abortion belongs to social ethics rather than to personal ethics. Sex and human life cannot be individualized. No matter who you are, what religion that you belong to, conscience tells each person that it is not enough for each of us to just keep away from having an abortion. We also have a responsibility to protect all human life and eliminate as much as possible the causes of abortion. This is also an important task for the good of society and of the nation.

The pro-life stance holds that a person's life or condition of a person begins at the moment of conception. It is always wrong to take the life of an innocent person directly. From the moment of conception, there was the life of an innocent person. Therefore, direct abortion is always immoral. In rare cases, it has to accept an abortion is to save the mother's life. As a moral principle, when two lives are threatened with death and the only one can be saved, doctors are forced to choose to save one of them immediately. There are cases where it is imperative to save the mother, but there are also many cases where it is possible to choose between the two, often the noble mother will be willing to sacrifice her life for her child to live.

Regarding the deformity of the child from the fetus, we have to note that the doctor's diagnosis is not always accurate. The rate of error and accuracy is sometimes about the same. On the other hand, the deformity of the baby from the fetus is usually very small. Moreover, the reality shows that children born with disabilities are often very happy, optimistic, and have strange energy to overcome adversity. When they became adults, they all expressed their happiness and pride in being accepted by their parents to be born. Reality proves that children 
with disabilities are not a burden on society. On the contrary, they themselves have made great efforts to contribute to the human community so many precious values.

Abortion due to rape or incest is also a matter of concern. Because pregnancy in this case is not the fault of the child/ fetus. It is the person who intentionally causes bad behavior to the woman is the guilty person, He is the one needs to be punished, not the completely innocent and pitiful child/ fetus. A child/fetus is always a child/fer Abortion due to rape or incest is also a matter of concern. Because pregnancy in this case is not the fault of the child/ fetus. It is the person who intentionally causes bad behavior to the woman is the guilty person, He is the one needs to be punished, not the completely innocent and pitiful child/ fetus. A child/fetus is always a child/fetus with full human dignity. No matter how it was conceived by any circumstances, whether through rape or incest. On the other hand, the violence of abortion to the woman herself is similar to the violence and immorality of the rape she has suffered. Abortion cannot help a woman who has been raped to feel comfort or find inner peace. Therefore, even in this particular case, one should not abort the fetus.us with full human dignity. No matter how it was conceived by any circumstances, whether through rape or incest. On the other hand, the violence of abortion to the woman herself is similar to the violence and immorality of the rape she has suffered. Abortion cannot help a woman who has been raped to feel comfort or find inner peace. Therefore, even in this particular case, one should not abort the fetus.

"Every human being has the inherent right to life. This right shall be protected by law. No one shall be arbitrarily deprived of his life (ICCPR, article 6)". Thus, among all human rights, the right to life must be affirmed as the most important right with the ultimate role. Because if a person does not have the right to live, everything and other rights for them also becomes meaningless. However, not everyone fully realizes their ultimate right, even quite a lot of people understand it in a very narrow sense that the right to life is the right to be protected by law for life and health only, it is not the right to be born.

In case, if it is not possible to be certain of when life began, the benefit of the doubt should be directed towards the preservation of life. Medical books and scientific studies repeatedly agree that human life begins at conception and should be granted the same rights as older, larger, and less vulnerable persons. We also know that the child/fetus can die and the mother is still alive, or the mother may die and the child live. It proves that they are separate individuals. The unborn child has an active role in the child's development, controlling the course of the pregnancy and the time of birth. Being in something is completely different from being part of something. People should not be discriminated against because of their place of residence or refuge (Alcorn, 2009, pp., 58-59).

There are many people who think that the unborn child is an embryo or a fetus, like a blob of tissue, that is a product of fertilization pregnancy rather than a child. Abortion is ending a pregnancy, not killing a child. But in terms of semanteme, a child is a child no matter what we call it. From the moment of conception, the unborn child is not a simple body, but a very complex one. Before the first 3 months of pregnancy, the unborn child already has everybody parts he/she will ever have. Every abortion stops a beating heart and terminates measurable brain waves. In the earliest stages of surgical abortions, the child is clearly human in appearance. No matter how good the reasoning is, termination of a pregnancy is the end of a life (Randy Alcorn, 2009, pp., 67-68). People today always use causes and circumstances to justify crimes such as murder. I think, crime itself is still a crime, which deserves to be avoided and punished, while the causes and circumstances of the crime must be eradicated and replaced by causes and circumstances that cause people to do good deeds.

Fetuses are both human and alive. Humans have the right to life. Therefore, fetuses have the right to life. Of course, women have the right to control their own bodies, but the right to life overrides the right of a woman to control her own body, if that fetus is not effective to her life (if the fetus is not the cause to dealing dead of the woman). Therefore, abortion is wrong. Everyone, whatever their race, sex, religion or age, have the right to live life. since the fetuses do not belong to another species, they are clearly human. Therefore, abortion is wrong, fetuses have the right to life (Scalet \& Arthur, 2016, pp. 556-557). 
The right to life of a fetus: Abortion is a serious moral and social problem of the young people in Vietnam

We also need to remember that specific rules are essential, but not sufficient for making an ethical decision. Since, each special situation may have own nooks and crannies leading the erroneous conscience. It is necessary to combine three basic principles when considering a problem. (1) consider people to be the end, (2) obey the laws of society, and (3) act according to conscience. If we just stick to principle one (1), we will fall into a moral utopia, which is too idealistic, abstract, impractical, and does not help solve concrete problems. If we just follow to the second rule (2), we can fall into a legalistic ethic, living according to traditional practices regardless of the changes or complexity of the situation. If you only keep the third (3) rules, we can fall into a kind of morality of individualism. An event has referential value only if it helps to respect people and uphold basic human values.

Thus, in all aspects and looking at the issue from different angles, abortion is still a condemnable; and protecting life is still considered ethical/moral, which brings more benefits to people and society. The Catholic Church does not accept abortion for any reason, except in the case of fetal death as a result of treatment to save the mother's life.

Suggestion for reducing abortion in the young Vietnamese people - Looking at the number of abortions mentioned above, abortion in the world as well as in Vietnam is horrible, even in environments where abortion is illegal. It is terrible because of its negative consequences to health, money, family, morality, religion, and society. Abortion is no longer a warning level; it is a really serious matter. Therefore, all societies, religions, ministries, departments, families, clans, and each of us have to do something to reduce abortion and its karma or consequences to humans. Banning abortion only will not solve anything without the right programs. Because abortion is just the last act of moral wrongdoing in a previous chain of moral wrongs of the people involved. It is not just only the abortionist involved in the sin of abortion, but also parents, boyfriends, husbands, and neighbors. The woman cannot get pregnant alone and it is also not easy for her to decide on abortion if there is no pressure from others and society Therefore, to reduce the abortion rate among young people, it is a long process, needs to be implemented in many aspects, and requires contributions from many people. Within the limits of this article, we cannot cover all the things that should be done. There are some important aspects that we need to concern for reducing abortion matter.

First, that is education, Education is the most important factor in deciding whether to increase or decrease the abortion rate among young people. All decisions and actions of a person mainly depend on that person's perception (Sarafino et al., 2020). To reduce abortion, we must pay attention to gender, sexuality and moral education for young people. This education helps them to have the right and healthy attitudes and understandings about sexuality. This work requires a combination of the school, the family and the young person themselves to provide an appropriate educational program such as about gender and sexuality education for young people, propaganda about safe and ethical methods of contraception, popularization and cognitive education on sexuality and abortion for all classes of people, especially for the youth. So that, they know to appreciate themselves, and also value the life that they have, are and will carry in their wombs. Through learning of sexuality, they can recognize new knowledge about sex, and reduce curiosity, controlling the psychology and sexuality, including increasing young people's knowledge and improving their attitudes related to sexual and reproductive health and behaviors. In the educational content, it is recommended to integrate and include the part about the fetus, identifying the right for this "new life", thereby improving the awareness for people, especially young people, to have more understanding about special aspects, about this right to life. By that status abortion will be reducing. Particularly, religions such as Catholicism, Buddhism, and Hinduism need to regularly educate their believers to learn and properly understand their teachings on abortion ethics. So that, they can live up to their morality and dignity. At the same time spread the spirit to others in society.

The second positive way to reduce abortion is to ensure that woman has the means to have and raise a child in health and safety by promoting "protecting life" activities such as helping women with unwanted pregnancies. They fear of not having enough condition to raise children. Others, like students, are afraid of public opinion and have no place to hide during pregnancy leading they want to abort. If it is helped timely, many of these people are willing to give birth, and then they can give the children to others or send them to an orphanage. Therefore, 
the State, charitable and religious organizations need to have policies to support these "protecting life" activities. Currently, in Vietnam, there are many centers for nurturing and helping women who have missed an unwanted pregnancy, they were built and operated by Catholic religious or Buddhist's temples. Thanks to that, many children were born instead of being killed in the womb. Most of the mothers who enter these centers, after giving birth, they will leave their children in the center, while the mother goes to build a new life. If later, the mother wants to take back her child for adoption, the center is willing to give the child to them. These are very practical and effective activities in reducing the number of abortions in Vietnam that we need to expand and promote further.

In addition, in order to reduce the need for abortion among young people, in addition to education and supportive policies as above, we need a healthy, friendly living environment, from within the family and the community. At the same time, the government must strictly punish those who rape women and girls leading to pregnancy because often, in these cases the first thing that comes to their mind is abortion if it is pregnant. For those who have already had an abortion. we should understand, share, and sympathize with those who have had an abortion in their life. Surely every woman who has had an abortion has experienced excruciating pain both mentally and physically. Whether they decide to have an abortion or not, bystanders cannot or should not judge. Social prejudices, as well as personal feelings, are sometimes the cause of more trauma than the decision to have an abortion or not. Abortion is really a difficult decision for a woman. Today, although abortion is less dangerous than before, there are still many women who had abortions endured terrible and long-lasting pain in the body and especially in the spirit. Because abortion causes very serious medical complications.

We need to determine that pregnancy is not a sin. Society has no right to condemn or pressure a pregnant woman who has not yet get married and push them into abortion. On the contrary, we should sympathize, support and support that woman. The wrong thing here is a loose lifestyle, a way of life without a good moral, sexual, and love education before marriage or outside of marriage. It is important that do not let this mistake causes another, which is more terrible, more profound wrong, and it is the obvious crime that is abortion

\section{Conclusion}

Life is a priceless gift that God has graciously given to man. As human beings, whether we are religious or non-religious, rich or poor, race or color, we have no right to decide or destroy the life and dignity of others. From an ethical point of view, there is no concept, no philosophy that can be considered to solve the problem in a radical, objective, and completely correct way when dealing with the abortion problem. Abortion or not depends on many different factors, not just a few simple aspects. Because a child is a human being from the moment, he is a fetus and must be protected like a human being born. They must have the right to live like anyone else, and so their mother has no right to have an abortion, which means no right to kill her child. The right to life also does not depend on the age, weight, or size of the child. The fetus has no less right to life than any older person, even in the case of its mother. The comparison between the interests of the child and the interests of the mother is a lame, unbalanced comparison. The nature of abortion shows that it is the mother who has tried everything to fight the life of her own child.

The issue of abortion has never ended, but there are always arguments and disagreements over generations. However, no matter what lens we look at the problem, only by starting from the general basis of the natural moral law as a principle or a point to be considered can we achieve a more just society with a greater sense of responsibility, a society in which individual interests are promoted and assimilated with the common good. (Goold et al., 2009). Many people asserted that the rate of abortions and the easy acceptance of abortion by society is directly proportional with the secularization degree of that society, because the secularized individuals live only for now and here and only to achieve their economic or social objectives, and they are willing to sacrifice not only their religious beliefs and principles but also the life of an unborn human being (Damian, 2010). "Respect for human life absolutely from its beginning to its last. As Don Marquis (1989) asserted in his article "except in unusual circumstances, abortion is seriously wrong"

60 Consortia Academia Publishing (A partner of Network of Professional Researchers and Educators) 
The right to life of a fetus: Abortion is a serious moral and social problem of the young people in Vietnam

\section{References}

Alcorn, R. (2009). Pro-life answers to pro-choice arguments. Crown Publishing Group.

Bearak, J., Popinchalk, A., Ganatra, B., Moller, A.-B., Tunçalp, Ö., Beavin, C., Kwok,L., \& Alkema, L. (2020). Unintended pregnancy and abortion by income, region, and the legal status of abortion: estimates from a comprehensive model for 1990-2019. The Lancet Global Health, 8(9), e1152-e1161. https://doi.org/10.1016/S2214-109X(20)30315-6

Beran, M. J., Perner, J., \& Proust, J. (2012). Foundations of Metacognition. OUP Oxford.

Bitler, M., \& Zavodny, M. (2002). Child abuse and abortion availability. American Economic Review, 92(2), 363-367. https://doi.org/10.1257/000282802320191624

Brown, M. T. (2000). The morality of abortion and the deprivation of futures. Journal of Medical Ethics, 26(2), 103-107. https://doi.org/10.1136/JME.26.2.103

Burkman, R. T., Atienza, M. F., \& King, T. M. (1984). Morbidity risk among young adolescents undergoing elective abortion. Contraception, 30(2), 99-105. https://doi.org/10.1016/0010-7824(84)90093-3

Bychawska-Siniarska, D. (2017). Protecting the right to freedom of expression under the European Convention on Human Rights: A handbook for legal practitioners, https://rm.coe.int/handbook-freedom-of-expression-eng/1680732814

Cao, K. X., Booth, A., Ourselin, S., David, A. L., \& Ashcroft, R. (2018). The legal frameworks that govern fetal surgery in the United Kingdom, European Union, and the United States. Prenatal Diagnosis, 38(7), 475-481. https://doi.org/10.1002/pd.5267

Cohen, S. A. (2009). Facts and consequences: legality, incidence and safety of abortion worldwide. Guttmacher Policy Review, 12(4), 2-6, http://www.guttmacher.org/pubs/gpr/12/4/gpr120402.html.

Duong, Thuy Nguyen. (2005). Feminist theories and consequences in today's context [Cac Ly thuyet Nu Quyen va He Qua Trong Boi Canh Ngay Nay]. Tap Chi Khoa, 2, ĐHKHXH\&NV Ha Noi.

Fernando, P. M. (2010). See, judge and act: Method for academic research. Quezon City: ICLA Publications.

Fieser, J. (2017, Oct. 1). Utilitarianism. Retrieved September 4, 2021, from https://www.utm.edu/staff/jfieser/class/300/utilitarian.htm

Florida, R. E. (1991). Buddhist approaches to abortion. Asian Philosophy, 1(1), 39-50. https://doi.org/10.1080/09552369108575334

Ganatra, B., Gerdts, C., Rossier, C., Johnson, B. R., Jr, Tunçalp, Ö., Assifi, A., Sedgh, G., Singh, S., Bankole, A., Popinchalk, A., Bearak, J., Kang, Z., \& Alkema, L. (2017). Global, regional, and subregional classification of abortions by safety, 2010-14: Estimates from a Bayesian hierarchical model. Lancet (London, England), 390(10110), 2372. https://doi.org/10.1016/S0140-6736(17)31794-4

George, R. P., \& Lee, P. (2009). Embryonic human persons. Talking Point on morality and human embryo research. EMBO reports, 10(4), 301-306. https://doi.org/10.1038/embor.2009.42

Goold, S. D., Williams, B. C., \& Arnold, R. (2009). Conflict in the healthcare setting at the end of life. In The Cambridge Textbook of Bioethics. https://doi.org/10.1017/cbo9780511545566.014.

Haring, B. (1981). Free and faithfull in Christ, vol. 3. St Paul Publications.

His Holiness the Dalai Lama. (1996). Beyond dogma dialogues and discourses. North Atlantic Books.

Inazumi, M. (2005). Universal jurisdiction in modern international law: Expansion of national jurisdiction for prosecuting serious crimes under international law. Intersentia nv.

John Paul II. (1995, Mar., 25). Evangelium vitae to the bishops priests and deacons men and women religious lay faithful and all people of good will on the value and inviolability of human life. Retrieved August 26, 2021, from https://www.vatican.va/content/john-paul-ii/en/encyclicals/documents/hf_jp-ii_enc_25031995_evangeli um-vitae.html

Keown, D. (1995). Buddhism and Bioethics. New York.

Kessler, g. E.. (2003). Voices of wisdom: A multicultural philosophy reader. Wadsworth.

Kuźniar, A., \& Odrowąż-Sypniewska, J. (2016). Uncovering facts and values: studies in contemporary epistemology and political philosophy. BRILL. 
Larios, S. (2015). Roe v. wade' s nightmare: the current legal state of abortion rights in the Dominican republic. Journal of International and Comparative Law, 5(2). https://scholarship.law.stjohns.edu/cgi/viewcontent.cgi?article=1033\&context=jicl

Lovers of Holy Cross. (2000). The constitution. Vinh.

Lysaught, T., Kotva, J., \& Lammers, S. E. (2012). On moral medicine: theological perspectives on medical ethics. Wm. B. Eerdmans Publishing.

Marquis, D. (1989). Why abortion is immoral. The Journal of Philosophy, 86(4), 183-202. https://doi.org/10.2307/2026961

Miklavcic, J. J., \& Flaman, P. (2017). Personhood status of the human zygote, embryo, fetus. The Linacre quarterly, 84(2), 130-144. https://doi.org/10.1080/00243639.2017.1299896

Narayan, R. (2018). Encyclopedia of biomedical engineering. Elsevier.

Ngoc Ha. (2014, August 08). Current status and causes of abortion among young people today [Thuc trang va Nguyen nhan pha thai cua gioi tre hien nay]. Retrieved August 15, 2021, from https://baoquangbinh.vn/xa-hoi-doi-song/201408/thuc-trang-va-nguyen-nhan-nao-pha-thai-cua-gioi-tre$\underline{\text { hien-nay-2117606/ }}$

Paine, J., Noriega, R. T., \& Puga, A. L. B. y. (2014). Using litigation to defend women prosecuted for abortion in Mexico: Challenging state laws and the implications of recent court judgments. Reproductive Health Matters, 22(44), 61-69. https://doi.org/10.1016/S0968-8080(14)44800-6

Paul VI. (1965). Gaudium Et Spes. Retrieved September 10, 2021, from https://www.vatican.va/archive/hist_councils/ii_vatican_council/documents/vat-ii_const_19651207_ga udium-et-spes_en.html

Paul VI. (1974). Sacred congregation for the doctrine of the faith, declaration on procured abortion. Retrieved August 23, 2021, from https://www.vatican.va/roman_curia/congregations/cfaith/documents/rc_con_cfaith_doc_19741118_de claration-abortion_en.html

Peschke, Karl-Heinz. (2012). Christian Ethics, Volume 2: Moral theology in light of Vatican II; Volume II, special moral theology, third edition. Wipf and Stock Publishers.

Pope Pius XII (1956) "Pope Pius XII to the guild of St. Luke," The Linacre Quarterly, 23(4), Article 2. Retrieved September 10, 2021, from https://epublications.marquette.edu/lnq/vol23/iss4/2

Quang Huyen. (2010, May 26). The conception of the life of the unborn child in Vietnamese culture [Quan niem ve su song cua thai nhi trong van hoa Viet Nam], posted by Katty Nguyen. Retrieved August 13, 2021, from http://baovesusongchongphathai.blogspot.com/2010/05/quan-niem-ve-su-song-cua-thai-nhi-trong.html

Sarafino, E. P., et al. (2020). Health psychology: Biopsychosocial interactions. John Wiley \& Sons.

Scalet, S., \& Arthur, J. (2016). Morality and moral controversies: Readings in moral, social and political philosophy, 9th edition. Routledge.

Solinger, R. (2019). The abortionist: A woman against the law. Univ of California Press, Xii.

Tam, Nguyen Van. (2004). The morality of procreation [Luan Ly Sinh San]. Ephata Vietnam.

The Holy See. (1983, Oct., 22). Charter of the rights of the family, Article 4. https://domesticchurch.com/CONTENT.DCC/BASEDOCS/charter.htm

Tomatis, A. (1981). La nuit utérine. Stock.

Trang, Khánh. (2004). factors affecting sexual behavior of high school students in HCM [Một số yếu tố ảnh hưởng hành vi quan hệ tình dục của học sinh cấp 3 tại Tp.HCM] Đại học Y dược Tp.HCM, Hồ Chí Minh.

Trang, Linh. (2020). Talk to your child about sex [Tro chuyen voi con ve gioi tinh]. Retrieved August 20, 2021, from https://nld.com.vn/giao-duc-khoa-hoc/tro-chuyen-voi-con-ve-gioi-tinh-20200829221230623.htm

Tsevat, D. G., Wiesenfeld, H. C., Parks, C., \& Peipert, J. F. (2017). Sexually transmitted diseases and infertility. American journal of obstetrics and gynecology, 216(1), 1-9. https://doi.org/10.1016/j.ajog.2016.08.008

Tsomo, K. L. (2012). Into the jaws of yama, lord of death: buddhism, bioethics, and death. Suny Press. 
The right to life of a fetus: Abortion is a serious moral and social problem of the young people in Vietnam

Turner, J. (2010). Maternity and paternity leave. In Manager (Issue Summer). https://doi.org/10.4135/9781452206905.n430

World Association for Medical Law. (1994). Medicine and law, volume 13. Springer International.

World Health Organization. (2017). Advancing the right to health: the vital role of law. World Health Organization. https://apps.who.int/iris/handle/10665/252815

Xiong, X., Fraser, W. D., \& Demianczuk, N. N. (2002). History of abortion, preterm, term birth, and risk of preeclampsia: a population-based study. American journal of obstetrics and gynecology, 187(4), 1013-1018. https://doi.org/10.1067/mob.2002.126282

Yadav, G. (2018) Abortion (Hinduism). In P. Jain, R. Sherma, and M. Khanna (Eds.), Hinduism and tribal religions. Encyclopedia of Indian Religions. Springer, Dordrecht. https://doi.org/10.1007/978-94-024-1036-5_484-1

Kao, Y.-Y. (2019). What's in it for me? On egoism and social contract theory. In Y. F. Aragbonfoh Abumere, D. Giles, M. Klenk, J. Kranak, K. MacKay, J. Morgan, P. Rezkalla, and G. Matthews (Eds.), Introduction to philosophy: Ethics (pp. 37-44). Rebus Community.

Ngọc Vy. (2021). 60-70\% of abortions are students [60-70\% cac ca pha thai la sinh viên va học sinh. Electronic Journal of Nhan Dan. Retrieved from https://nhandan.vn/tin-tuc-xa-hoi/60-70-cac-ca-pha-thai-la-sinh-vien-va-hoc-sinh-643226/ 
Lan, N. T. 